\title{
PELATIHAN BAHASA INGGRIS DASAR BAGI WARGA BABAKAN CANGGU, BADUNG-BALI
}

\author{
I Made Juliarta ${ }^{1 *}$, I Gede Nika Wirawan ${ }^{1}$ \\ ${ }^{1}$ Program Studi Bahasa Inggris, Universitas Bali Dwipa \\ 2Program Studi Sistem Informasi, ITB Stikom Bali \\ ${ }^{*}$ Coresponding-Author : madejuliarta330@gmail.com
}

\begin{abstract}
ABSTRAK. Kegiatan pengabdian kepada masyarakat yang dilaksanakan di Banjar Babakan Canggu Badung ini bertujuan untuk meningkatkan kemampuan Bahasa Inggris dasar bagi warga Banjar Babakan Canggu dengan memberikan pelatihan. Program pelatihan Bahasa Inggris Dasar ini dilaksanakan berkat Kerjasama antara Prodi Bahasa Inggris, Universitas Bali Dwipa dan masyarakat sekitar di Banjar Babakan Canggu Badung Bali. Kegiatan Pengabdian kepada Masyarakat dalam bentuk pelatihan Bahasa Inggris dasar ini diselenggrakan selama 4 bulan di wilayah Br. Babakan Canggu, Kuta Utara, Badung. Adapun Metode persuasive yang diaplikasikan dalam proses pembelajaran dengan jenis penelitian kualitatif. Metode pengumpulan data dilakukan berdasarkan observasi yaitu dengan mengamati fenomena yang terjadi di lapangan. Adapun pelatihan yang diberikan kepada peserta antara lain pelatihan Bahasa Inggris dasar.Semua peserta yang merupakan warga Br. Babakan Canggu nampak sangat antusias di dalam mengikuti pelatihan Bahasa Inggris dasar ini. Setelah diberikan pelatihan Bahasa Inggris dasar, kemampuan Bahasa Inggris para peserta meningkat dilihat dari kemampuan berbicara dalam Bahasa Inggris. Proses pelatihan bahasa Inggris ini diberikan kepada warga Br. Babakan, canggu didasari atas tulus iklas.
\end{abstract}

Kata Kunci: Bahasa Inggris; Pelatihan, Penelitian Kualitatif

\begin{abstract}
The community service activity which was held in Banjar Babakan Canggu Badung aims to improve basic English skills for Banjar Babakan Canggu residents by providing training. This Basic English training program was carried out thanks to the collaboration between the English Language Study Program, Bali Dwipa University and the surrounding community in Banjar Babakan Canggu Badung Bali. This community service activity in the form of basic English training was held for 4 months in the area of Br. Babakan Canggu, North Kuta, Badung. The persuasive method applied in the learning process is qualitative research. The data collection method is based on observation, namely by observing the phenomena that occur in the field. The training provided to the participants included basic English language training. All participants who were citizens of Br. Babakan Canggu seems very enthusiastic about participating in this basic English training. After being given basic English training, the participants' English skills improved in terms of their speaking ability in English. The process of training in English was given to residents of Br. Babakan, canggu based on sincere sincerity.
\end{abstract}

Keyword: English; Training, Qualitative Research

\section{PENDAHULUAN}

Penguasaan Bahasa Asing terutama Bahasa Inggris memang sangat penting guna bisa bersaing dalam dunia kerja maupun di tingkat Internasional. Didalam dunia kerja, Bahasa Inggris digunakan ketika melakukan komunikasi dengan orang asing yang mana harus menguasai Bahasa Inggris dengan baik. Dunia kerja khususnya pariwisata, memerlukan penguasaan Bahasa Inggris yang baik agar bisa memberikan pelayan yang baik ketika melakukan komunikasi dengan tamu wisatawan asing. 
Bahasa Inggris hingga kini digunakan sebagai mata pelajaran wajib bagi peserta didik dari tingkat taman kanak-kanak sampai perguruan tinggi. Bahasa Inggris kini menjadi mata pelajaran yang bisa di UN-kan. Bahasa Inggris merupakan bahasa yang sangat penting untuk dipelajari karena dapat menjadi faktor penentu dalam mencapai kemajuan suatu bangsa. Dampak positif dari penggunaan bahasa Inggris adalah dapat mengikuti perkembangan di dunia. Bahasa Inggris juga memiliki peranan yang sangat penting terutama di dunia kerja.

Bahasa Inggris merupakan bahasa internasional yang memiliki peranan yang sangat penting dalam menghadapi kemajuan teknologi sebab bahasa asing memliki peranan yang sangat penting guna menghadapi kondisi saat ini. Dengan menguasai kemampuan Bahasa Inggris, maka bisa memudahkan kita untuk mencari pekerjaan dan bisa bersaing di dunia kerja. Bahasa Inggris juga memiliki peranan yang sangat penting bagi kemajuan masyarakat di Indonesia. Dengan menggunakan metode deskriptif, kita bisa mengetahui peranan Bahasa Inggris khususnya di dalam dunia pendidikan di Indonesia karena Bahasa Inggris tersebut memiliki peranan yang sangat penting dan berpengaruh dalam pendidikan yang ada di Indonesia.

Berdasarkan fenomena di atas, penulis tertarik untuk memberikan pelatihan Bahasa Inggris dasar bagi warga Br. Babakan Canggu Badung-Bali guna meningkat kemampuan peserta didik khusunya dalam penguasaan Bahasa Inggris dasar. Metode Teknik pengumpulan data dilakukan berdasarkan observasi yaitu dengan mengamati fenomena yang terjadi di lapangan ketika memberikan pelatihan Bahasa Inggris dasar. Adapun pelatihan yang diberikan kepada peserta antara lain pelatihan Bahasa Inggris dasar.Semua peserta yang merupakan warga $\mathrm{Br}$. Babakan Canggu nampak antusias di dalam mengikuti pelatihan Bahasa Inggris dasar ini. Materi pelatihan Bahasa Inggris yang diberikan yaitu kemampuan berbicara, mendengarkan dan penguasaan koasakata Bahasa Inggris umum. Setiap peserta pelatihan Bahasa Inggris dasar ini didampingi oleh pengajar yang berpengalaman dalam memberikan pelatihan Bahasa Inggris dasar ini. Dengan didampingi langsung oleh pembimbing, maka peserta pelatihan Bahasa Inggris dasar ini bisa meningkatkan kemampuan Bahasa Inggrisnya dengan baik. Adapun tujuan diberikannya pendampingan langusng ini yaitu agar pembimbing pelatihan Bahasa Inggris dasar ini bisa memantau proses kegiatan belajar mengajar yang diberikan oleh pembimbing. Selain itu juga, peserta pelatihan menjadi lebih akrab dengan pengajar pelatihan Bahasa Inggris ini. DEngan menciptakan suasana yang akrab, maka para peserta pelatihan Bahasa Inggrsi dasar ini bisa menikmat kegiatan belajar mengajar ini dengan baik.

\section{SOLUSI YANG DITAWARKAN}

Metode persuasive merupakan metode yang digunakan dalam proses pembelajaran Bahasa Inggris. Metode pengumpulan data ini telah dilakukan berdasarkan observasi yaitu dengan mengamati fenomena yang terjadi di tempat pelatihan Bahasa Inggris. Adapun pelatihan yang diberikan kepada peserta antara lain pelatihan Bahasa Inggris dasar. Semua peserta yang merupakan warga $\mathrm{Br}$. Babakan Canggu nampak sangat antusias di dalam mengikuti pelatihan Bahasa Inggris dasar ini. Laporan Pengabdian kepada Masyarakat ini juga menggunakan metode pendekatan kualitatif. Lebih lanjut, Bogdan dan Taylor dalam Moleong (2010:4) menjelaskan bahwa metodologi penelitian kualitatif sebagai prosedur penelitian yang menghasilkan data deskriptif berupa kata-kata tertulis atau lisan dari orang-orang dan perilaku yang bisa kita amati. Penelitian Pengabdian kepada Masyarakat ini juga menggunakan teori Muhammad (2011: 30) yang mengungkapkan bahwa penelitian kualitatif merupakan jenis penelitian dengan paradigma pospositivism, yang memiliki tujuan untuk menafsirkan objek yang akan diteliti, dengan menggunakan beberapa metode dan dilaksanakan pada latar alamiah. Selanjutnya, Ismawati (2012: 9) mengemukakan bahwa penelitian kualitatif merupakan metode kualitatif karena beberapa faktor. Diantaranya yaitu pertama, lebih mampu mengungkap realitas ganda, kedua, lebih mengungkapkan 
hubungan wajar antara peneliti dengan responden, dan ketiga, merupakan metode pendekatan kualitatif yang lebih sensitif dan adaptif terhadap peran sebagai pengaruh timbal balik.

Kegiatan pelatihan bahasa Inggris ini menggunakan data primer yang merupakan interaksi antara peserta didik dan pengajar. Misalnya, pendidik mengajar dengan gerakan tubuh guna mempercepat pemahaman peserta didik dalam melakukan pelatihan Bahasa Inggris ini. Di dalam memberikan pelatihan bahasa Inggris tingkat dasar, gerakan tubuh diperlukan guna mempercepat pemahaman terhadap materi yang disampaikan dalam proses belajar mengajar ini. Peserta nampak antusias di dalam proses pembelajaran ini, sehingga membuat pendidik bersemangat di dalam memberikan pelatihan Bahasa Inggris kepada warga yang tinggal di sekitar wilayah $\mathrm{Br}$ Babakan, Canggu-Badung, Bali. Diharapkan, setelah mengikuti proses belajar mengajar ini para peserta pelatihan ini bisa menggunakan ilmu yang didapat baik di dunia kerja maupun di dalam kegiatan sehari-hari.

\section{HASIL DAN PEMBAHASAN}

Peserta yang mengikuti pelatihan Bahasa Inggris dasar ini merupakan warga $\mathrm{Br}$. Babakan, Canggu, Badung-Bali. Peogram ini merupakan kerja sama antar Program Studi Bahasa Inggris, Universitas Bali Dwipa dengan konsultan Bahasa, Canggu, Badung-Bali yang berlokasi di $\mathrm{Br}$ Babakan Canggu, Badung-Bali. Materi yang diberikan kepada peserta pelatihan ini merupakan materi Bahasa Inggris dasar. Materi bahan ajar yang menyenangkan membuat peserta didik pelatihan Bahasa Inggris ini sangat antusias ketika mengikuti program latihan ini. Adapun materi bahan ajar yang diberikan kepada peserta pelatihan Bahasa Inggris umum ini, yaitu tentang penguasaan kosa-kata, grammar, mendengarkan, membaca dan melakukan percakapan. Disamping itu juga diberikan pembekalan dalam penguasaan tenses yang ada dalam Bahasa Inggris. Pengajar memberikan selingan materi Bahasa Inggris dalam proses pembelajaran yaitu materi tentang mendengarkan tentang percakapan Bahasa Inggris. Nampak peserta sangat antusias ketika menyimak materi penjelasan yang diberikan oleh pengajar.

Materi bahan ajar membaca diberikan kepada para peserta pelatihan Bahasa Inggris ini guna meningkatkan kemampuan membaca dalam Bahasa Inggris ini. Dengan memberikan pelatihan membaca dalam Bahasa Inggris, para peserta bisa meningkatkan pengucapan dalam membaca naskah dalam Bahasa Inggris. Materi bacaan yang diberikan kepada para peserta yaitu materi dasar yang mengandung kosa-kata tingkat dasar dalam Bahasa Inggris. Tujuan diberikannya kegiatan membaca ini agar para peserta pelatihan tidak merasa jenuh dalam pelaksanaan belajar mengajar ini. Pendampingan dalam rposes membaca juga dilakukan oleh pengajar agar bisa memantau perkembangan peserta didik Pengabdian kepada Masyarakat ini. Materi bacaan yang diberikan merupakan materi yang menyenangkan guna menghilangkan kepenatan belajar mengajar di kelas.

Kegiatan English writing juga diberikan kepada para peserta pelatihan Bahasa Inggris dasar ini guna meningkatkan kemampuan dalam menulis Bahasa Inggris. Para peserta nampak sangat menikmati kegiatan menulis dalam Bahasa Inggris yang diberikan oleh pengajar ini. Kegiatan yang dilaksanakan di dalam ruangan kelas ini membuat para peserta Pengabdian kepada Masyarakat menikmati suasana belajar yang menyenangkan ini. Pelatihan menulis ini juga bertujuan untuk meningkatkan kemampuan English grammar para peserta Pengabdian kepada Masyarakat. Para peserta Pengamas ini, juga telah diberikan tata cara menulis yang baiak dalam Bahasa Inggris. Sehingga, mereka bisa menguasai kemampuan menulis dalam Bahasa Inggris dengan baik. Kemampuan dalam menguasai grammar memang sangat penting dalam menulis dalam Bahasa Inggris. Materi menulis yang diberikan yaitu tentang materi menulis dasar dalam Bahasa Inggris. Tenses yang digunakan yaitu dalam bentuk simple present tense, past tense dan simple future tense. Selain itu jega peserta pelatihan Pengabdian kepada Masyarakat ini diberikan selingan permainan yang masih berhubungan dengan pelajaran Bahasa Inggris untuk menciptakan suasana 
belajar yang menyenangkan di dalam kelas. Terlihat para peserta Pengabdian kepada Masyarakat ini sangat terhibur setelah diberikan permainan dalam Bahasa Inggris dasar ini. Dengan diberikan permainan Bahasa Inggris ini, para peserta bisa memahami pelajaran yang diberikan dengan mudah. Selain itu juga untuk menghilangkan rasa jenuh selama proses pembelajaran berlangsung. Materi permainan Bahasa Inggris ini dalam bentuk permainan Bahasa Inggris dasar dengan materi yang sudah dipelajari oleh peserta sebelumnya. Permainan kartu merupakan salah satu contoh permainan Bahasa Inggris dasar yang diberikan kepada peserta pelatihan Pengabdian kepada Masyarakat ini.

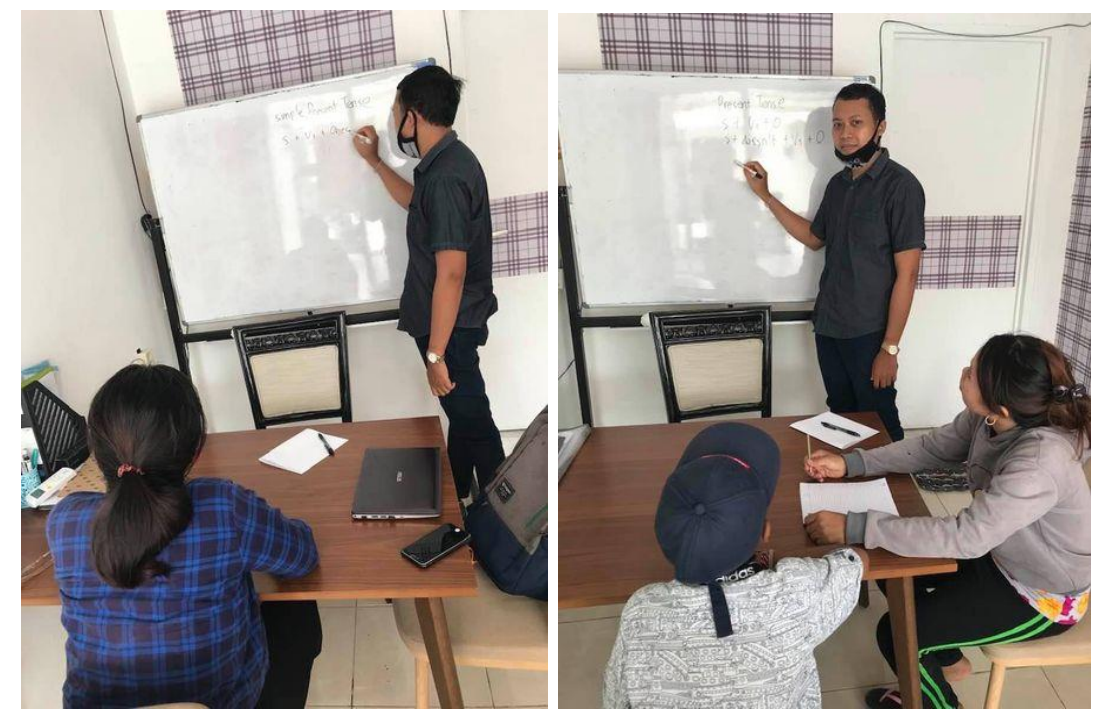

Kegiatan belajar mengajar peserta

\section{KESIMPULAN}

Kegiatan Pengabmas yang dilaksanakan di Banjar Babakan Canggu Badung ini bertujuan untuk meningkatkan kemampuan Bahasa Inggris dasar bagi warga Banjar Babakan Canggu dengan memberikan pelatihan Bahasa Inggris dasar. Program pelatihan Bahasa Inggris dasar ini dilaksanakan berkat kerjasama antara Prodi Bahasa Inggris, Universitas Bali Dwipa dan masyarakat sekitar di Banjar Babakan Canggu Badung Bali. Kegiatan Pengabmas dalam bentuk pelatihan Bahasa Inggris dasar ini diselenggarakan selama 4 bulan di wilayah Br. Babakan Canggu, Kuta Utara, Badung. Adapun metode penelitian yang digunakan yaitu metode persusif yang telah digunakan dalam proses pembelajaran dengan jenis penelitian kualitatif. Metode pengumpulan data telah dilakukan berdasarkan teknik observasi yang dilakukan yaitu dengan mengamati fenomena yang terjadi di lapangan. Adapun pelatihan yang diberikan kepada peserta antara lain pelatihan Bahasa Inggris dasar. Semua peserta yang merupakan warga Br. Babakan Canggu, Badung Bali nampak sangat antusias di dalam mengikuti pelatihan Bahasa Inggris dasar ini. Setelah diberikan pelatihan Bahasa Inggris dasar, kemampuan Bahasa Inggris para peserta meningkat setelah dilihat dari kemampuan berbicara dalam Bahasa Inggris. Proses pelatihan bahasa Inggris ini diberikan kepada warga $\mathrm{Br}$. Babakan, canggu didasari atas tulus iklas.

\section{REFERENSI}

Burgon \& Huffner. 2002. Human Communication. London: Sage Publication

Chaer, A. 2013. Pembinaan Bahasa Indonesia. Jakarta: PT Rineka Cipta.

Ismawati, Esti. 2012. Metode Penelitian Pendidikan Bahasa dan Sastra. Yogyakarta: Penerbit Ombak.

Moleong. 2010. Metodologi Penelitian Kualitatif. Bandung: PT Remaja Rosdakarya. 
Muhammad. 2011. Metode Penelitian Bahasa. Jogjakarta: Ar-Ruzz Media.

Muslich, M. 2010.Bahasa Indonesia Pada era Globalisasi. Jakarta: PT Bumi Aksara.

Murti, Sri. Eksistensi Penggunaan Bahasa Indonesia di Era Globalisasi. Prosiding Seminar bulan Bahasa UNIB 2015. hlm:177-184.

Nisa, K \& Imam Suyitno. 2017. Kesalahan Penggunaan Bahasa Indonesia dalam Teks Terjemahan Mahasiswa. Jurnal Basindo, 1(1).

Pamungkas, Sri. 2012. Bahasa Indonesia dalam berbagai perspektif. Yogyakarta: Penerbit Andi.

Paryono, Y. 2013. Peran Strategis Media Massa Dalam Pembinaan Dan Pengembangan Bahasa Indonesia. Jurnal Madah. 4(2). 